\title{
Developing Clinical Faculty Understanding of Interprofessional Education: An Inter-institutional, Interprofessional Approach
}

\author{
Debra A. Bierwas \\ Midwestern University, dbierw@midwestern.edu \\ Oaklee Rogers \\ Northern Arizona University \\ Brenda Taubman \\ Midwestern University \\ Lorie Kroneberger \\ Northern Arizona University \\ Holly Carroll \\ Northern Arizona University
}

See next page for additional authors

Follow this and additional works at: https://nsuworks.nova.edu/ijahsp

Part of the Interprofessional Education Commons, and the Rehabilitation and Therapy Commons

\section{Recommended Citation \\ Bierwas DA, Rogers O, Taubman B, Kroneberger L, Carroll H, Enking P. Developing Clinical Faculty Understanding of Interprofessional Education: An Inter-institutional, Interprofessional Approach. The Internet Journal of Allied Health Sciences and Practice. 2017 Jan 01;15(4), Article 9.}

This Manuscript is brought to you for free and open access by the College of Health Care Sciences at NSUWorks. It has been accepted for inclusion in Internet Journal of Allied Health Sciences and Practice by an authorized editor of NSUWorks. For more information, please contact nsuworks@nova.edu. 


\title{
Developing Clinical Faculty Understanding of Interprofessional Education: An Inter-institutional, Interprofessional Approach
}

\begin{abstract}
Introduction: The call for increasing interprofessional education requires institutional support for educators in the clinical environment. Innovative ideas, such as partnering with multiple universities and programs to facilitate an interprofessional workshop, have the opportunity to reach a broader group of clinical educators. The purpose of this study was to examine the attitude of healthcare professionals towards interprofessional learning, familiarity with concepts of interprofessional teaching, and interprofessional practice, and to examine the influence of an interprofessional faculty development workshop on participant familiarity with concepts of interprofessional teaching and learning. Methods: The occupational therapy, physical therapy, and physician assistant programs from two universities collaborated to implement an all-day inter-institutional, interprofessional clinical faculty development workshop. Community clinical educators who participated in the event were surveyed pre- and postworkshop to examine their attitude, readiness, and knowledge of interprofessional learning and teaching. Using the revised version of the Readiness of Interprofessional Learning Scale, the following subscales were measured and analyzed: 1) Teamwork and Collaboration, 2) Negative Professional Identity, 3) Positive Professional Identity, and 4) Roles and Responsibilities. Results: Forty-three participants representing six different healthcare professions completed pre- and post-course surveys. Forty-four percent reported participating in interprofessional education. Overall, the attendees reported the value of the workshop as a 4.6 on a 5.0 point Likert scale, with 5.0 being the highest rating. Self-reported familiarity of the fundamental concepts of interprofessional teaching, interprofessional practice, and interprofessional education improved up to $32 \%$ following participation in the workshop. The highest increase in familiarity was in the area of knowledge of interprofessional practice and education. Participants reported high levels of agreement about the value of teamwork, collaboration, and positive professional identity. Conclusion: Integrating the Core Competencies for Interprofessional Collaborative Practice into educational programs and clinical practice can facilitate improved understanding of professional roles and improved collaborative practice.
\end{abstract}

\section{Author Bio(s)}

Debra Bierwas, PT, DPT, DHSc is the Director of Clinical Education and Assistant Professor at the Physical

Therapy Program, Midwestern University, 19555 N. $59^{\text {th }}$ Avenue, Glendale, AZ, 85308 (dbierw@midwestern.edu). Please address all correspondence to Debra Bierwas.

Oaklee Rogers, OTD, OTR/L is the Academic Fieldwork Coordinator and Assistant Clinical Professor at Northern Arizona University in Phoenix, AZ.

Brenda Taubman, PhD, OTR/L is an Assistant Professor and Coordinator of Clinical Education at Midwestern University, Glendale, AZ.

Lorie Kroneberger, PT, DPT, GCS is an Associate Clinical Professor and Academic Coordinator of Clinical Education at Northern Arizona University in Flagstaff, AZ.

Holly Carroll, PT, DPT is an Assistant Clinical Professor and Academic Coordinator of Clinical Education at Northern Arizona University in Phoenix, AZ.

Patrick Enking, MS, PA-C is a Professor and Director of Clinical Education at the University of Nevada, Reno, NV. 


\section{Authors}

Debra A. Bierwas, Oaklee Rogers, Brenda Taubman, Lorie Kroneberger, Holly Carroll, and Patrick Enking 


\title{
IUAHSP \\ The Internet Joumnal of Allied Health Sciences and Practice \\ Dedicated to allied health professional practice and education
}

Vol. 15 No. 4 ISSN 1540-580X

\section{Developing Clinical Faculty Understanding of Interprofessional Education: An Inter-institutional, Interprofessional Approach}

\author{
Debra A. Bierwas, PT, DPT, DHSc ${ }^{1}$ \\ Oaklee Rogers, OTD, OTR/L² \\ Brenda Taubman, PhD, OTR/L 1 \\ Lorie Kroneberger, $\mathrm{PT}, \mathrm{DPT}^{2}$ \\ Holly Carroll, PT, DPT ${ }^{2}$ \\ Patrick Enking, MS, PA-C 3 \\ Midwestern University ${ }^{1}$ \\ Northern Arizona University2 \\ University of Nevada, Reno ${ }^{3}$
}

United States

\begin{abstract}
Introduction: The call for increasing interprofessional education requires institutional support for educators in the clinical environment. Innovative ideas, such as partnering with multiple universities and programs to facilitate an interprofessional workshop, have the opportunity to reach a broader group of clinical educators. The purpose of this study was to examine the attitude of healthcare professionals towards interprofessional learning, familiarity with concepts of interprofessional teaching, and interprofessional practice, and to examine the influence of an interprofessional faculty development workshop on participant familiarity with concepts of interprofessional teaching and learning. Methods: The occupational therapy, physical therapy, and physician assistant programs from two universities collaborated to implement an all-day inter-institutional, interprofessional clinical faculty development workshop. Community clinical educators who participated in the event were surveyed pre- and postworkshop to examine their attitude, readiness, and knowledge of interprofessional learning and teaching. Using the revised version of the Readiness of Interprofessional Learning Scale, the following subscales were measured and analyzed: 1) Teamwork and Collaboration, 2) Negative Professional Identity, 3) Positive Professional Identity, and 4) Roles and Responsibilities. Results: Forty-three participants representing six different healthcare professions completed pre- and postcourse surveys. Forty-four percent reported participating in interprofessional education. Overall, the attendees reported the value of the workshop as a 4.6 on a 5.0 point Likert scale, with 5.0 being the highest rating. Self-reported familiarity of the fundamental concepts of interprofessional teaching, interprofessional practice, and interprofessional education improved up to $32 \%$ following participation in the workshop. The highest increase in familiarity was in the area of knowledge of interprofessional practice and education. Participants reported high levels of agreement about the value of teamwork, collaboration, and positive professional identity. Conclusion: Integrating the Core Competencies for Interprofessional Collaborative Practice into educational programs and clinical practice can facilitate improved understanding of professional roles and improved collaborative practice.
\end{abstract}

\section{INTRODUCTION}

The increasing complexity of the healthcare system in the United States raises concerns about the quality and safety of health care delivery. The optimal delivery of health care cannot be addressed by one profession in isolation of others. Teamwork and communication skills beyond those previously required among healthcare professionals, (a term used to refer to healthcare workers from different disciplines who provide patients with preventive, curative, and rehabilitative care) have become imperative. ${ }^{1-5}$ Research suggests that when a variety of professionals develop ways to collaborate on the approach of the health needs of the client, family, and population under their care, they are practicing in an integrated and cohesive manner often 
referred to as interprofessionality. ${ }^{1,2,6}$ D'Amour specifically describes interprofessionality as "an approach to care and education where educators and practitioners collaborate synergistically."2p10

In order for a health professional or health profession student to become proficient with interprofessionality, they will need to learn and develop the skills and traits through interprofessional education. The World Health Organization (WHO) defines interprofessional education as "students from two or more professions learning about, from, and with each other to enable effective collaboration and improve health outcomes."7p13 Interprofessional education is being increasingly recognized as necessary to include in health professions' education in an effort to facilitate interprofessionality in practice and is now a standard that is required by most health profession education accrediting bodies. ${ }^{8,9}$ Research supports that interprofessional education should occur when the students are at the point of their educational program where they have developed a professional identity which allows them to contribute to the interprofessional learning. ${ }^{10}$ This may be done in the classroom and/or in clinical practice.

Reeves et al updated a previous Cochrane review with nine new interprofessional education studies. ${ }^{11}$ The purpose of their review was to assess the effectiveness of interprofessional education compared to separate, profession-specific education interventions and to assess the effectiveness of interprofessional education interventions compared to no education intervention. Their review of 15 rigorous studies included randomized control trials, controlled before and after studies, and interrupted time series studies. A range of positive outcomes were reported from these studies, but the researchers concluded that as a result of the heterogeneity of the interprofessional education interventions, drawing generalizable inferences for the effects of interprofessional education was not possible. They further concluded that additional "rigorous interprofessional education research is needed to demonstrate evidence of the impact of this type of intervention on professional practice or healthcare outcomes, or both."11p16

Russell et al conducted qualitative and quantitative analyses of the interprofessional learning environment of both a medical and a surgical unit in a tertiary care teaching hospital providing clinical training for various health profession students. ${ }^{6}$ Two survey instruments were used to measure attitudes toward interprofessional practice of medical, nursing, and other health professional staff (e.g., social work, pharmacy, physical therapy, occupational therapy, speech language pathology, and nutrition) and students working on the two units. A total of 62 surveys were completed, 43 from staff and 19 from students. The survey results confirmed the researchers' hypothesis that there was little explicit interprofessional education for health professions students. "The environment in which they do their clinical training seems largely bereft of individual or organizational models of interprofessional behavior...."6036

Some of the problems hindering collaborative practice identified in the literature include differing professional and cultural beliefs and attitudes among healthcare professionals, stereotypes of one's own and other professions, communication and relationship patterns deeply embedded in professional identities, and educators and mentors who are role models who can sometimes be barriers, rather than enablers, as they shape students' professional identities. $1,2,6,12-14$ Several solutions have been proposed to address these problems. A vision of interprofessionality at the institutional level is fundamental. Faculty from multiple disciplines who value interprofessional education are needed to design curriculum that fosters collaboration and teamwork across disciplines. They can introduce interprofessional education opportunities to increase familiarity with conceptual models, roles, and responsibilities among the disciplines to reduce the competitive mindset and create mutual trust. Perhaps one of the most important solutions noted is to expose students to clinical settings where collaborative practice is modeled for learners ${ }^{1,2}$ Implementing these solutions can provide the benefits of interprofessionality, which include enhanced communication and conflict resolution among healthcare professionals, and reduced cost and greater responsiveness for the healthcare system. 1,2,12

\section{Problem Statement}

Curricula in health professions education necessarily differs among the various clinical training programs. However, to offer optimal care, students must also learn common skills and the ability to approach patients with a strong understanding of what each member of the team can offer in terms of health, wellness, and disease management. Regardless of this fact, there are few opportunities for them to interact and learn with peers from other disciplines. The literature describes mostly short courses or workshops inserted into a standard curriculum, and usually only in a preclinical setting. ${ }^{6}$ Consequently, learning and understanding each other's roles and practicing collaboration and teamwork as students continues to be somewhat limited. ${ }^{1}$ This results in a disconnect between health professions education and the dynamic which is necessary in the healthcare industry: interprofessional, collaborative practice. As increasing interest lies in assessing interprofessional collaboration within the world of clinical educators in a variety of allied health practices, information about how these professionals work together can direct future efforts in developing effective interprofessional education student programs.

(c) The Internet Journal of Allied Health Sciences and Practice, 2017 


\section{Purpose of the Study}

The purpose of this study was to examine the attitudes of healthcare professionals toward interprofessional learning, familiarity with concepts of interprofessional teaching and practice, and to examine the influence of an interprofessional faculty development workshop on participant familiarity with concepts of interprofessional teaching and learning.

\section{METHODS}

The faculty of the occupational therapy, physical therapy, and physician assistant programs at both Northern Arizona University and Midwestern University, under the guidance of the Clinical Faculty Development Center of the University of Massachusetts (UMASS) Medical School, collaborated in designing and implementing The Interprofessional Clinical Educator Development Workshop in Phoenix, Arizona. Sponsored in part by a Heath Resources Service Administration Primary CareTraining grant, the researchers hosted 43 community-based educators from the six programs for the one-day, interactive program. The agenda was developed to illustrate and engage the attendees in interprofessional teaching and learning opportunities available in the clinical setting (Appendix 1).

The objectives of the workshop were to 1) understand and identify the benefits and challenges of interprofessional education and interprofessional collaborative practice, 2) list and apply the characteristics of good teachers and good teaching, 3) use an educational framework to plan effective teaching encounters, 4) describe and apply four teaching/questioning styles used to perform a needs assessment, 5) discuss the elements of effective learner evaluations, and 6) develop and practice giving effective feedback, which includes developing an action plan.

Prior to the delivery of the workshop content, all subjects reviewed and signed an informed consent document indicating an anonymous survey was being administered to access a foundational understanding of the familiarity of interprofessional concepts for education and practice. The study procedures were reviewed and approved by the Northern Arizona University institutional review board.

To accomplish the objectives, the team created and utilized lecture style instruction to deliver foundational concepts, engaged in role-play and modeling of interventional techniques by core faculty members, and facilitated experiential small group activities. Initially, foundational concepts of interprofessional collaborative practice and education were reviewed. The importance of working in teams and the benefits and challenges of interprofessional education were outlined. In another session, the discussion was focused on qualities that make a "good" teacher and learner. Finally, an educational process was introduced to the teams that included how to define goals, identify needs, write objectives, determine teaching methods, and evaluate performance (GNOME) when working with students.

Upon completion of foundational concepts delivery, core faculty members worked with one of six small interprofessional groups of conference attendees during role-play activities. This exercise required participants to provide effective feedback to a healthcare student, assess their own learning and teaching style, and provide effective communication to healthcare students in a clinical setting. Group members simulated the role of either a "clinical educator," "student," or "observer" to act out case based scenarios. Examples of case vignettes that participants worked through during one small group session included 1) a very anxious healthcare student who must talk with a 21 -year-old woman with pain with intercourse; 2) a 40-year-old female with a spinal cord injury who is worried and has difficulty focusing; 3 ) a 50-year-old male with a left stoke who has cognitive and motor impairments and becomes angry at the entire healthcare team; 4) a 2-year-old female with cerebral palsy whose mother is non-compliant with her therapy, and the healthcare student who wants to file a "Child Neglect Form" with the state.

Upon the conclusion of the workshop, the researchers administered the same survey to capture data for an assessment of any change in the familiarity of interprofessional concepts for education and practice. All data collected was anonymous.

\section{Instrument}

Selecting a valid and reliable tool to conduct the survey was challenging and revealed limited options that would provide sound psychometric properties for measuring familiarity and readiness for preceptors to engage collaboratively within the common fields of treatment, education, and research. ${ }^{16}$ Although there are numerous tools published that measure different aspects of interprofessional education, research on interprofessional collaborative care within the healthcare system reveals problems with available instruments that may include conflicting reports on validity, lack of standardization of key terminology, and lack of psychometric evaluation. ${ }^{16,17}$ After review of the various survey tools available, the Readiness for Interprofessional Learning Scale (RIPLS) revised version developed by McFayden was selected for use in this study. ${ }^{17-19}$ This instrument allowed researchers to collect information about participant attitudes about interprofessional learning. Parsell and Bligh originally

(C) The Internet Journal of Allied Health Sciences and Practice, 2017 
published this survey instrument to examine the attitude of health and social care students towards interprofessional learning and measure participants' readiness to engage in interprofessional education. ${ }^{20}$ Revisions were made to improve reliability of the instrument. ${ }^{19} \mathrm{It}$ is a nineteen-item self-report inventory that is scored using a 5-point Likert scale and includes the following subscales: 1) Teamwork and Collaboration, 2) Negative Professional Identity, 3) Positive Professional Identity, and 4) Roles and Responsibilities. ${ }^{19,21}$ It has been used with undergraduate and post-graduate healthcare professionals, but may be unreliable for undergraduate students who lack experience. ${ }^{21-23}$ The instrument has been validated for use with postgraduate professionals. ${ }^{22}$ In the evaluation of test-retest reliability, of the sub-scales, three demonstrated intraclass correlation coefficient values that were acceptable ranging from 0.61 to $0.71 .{ }^{21}$ The revised instrument is available in the public domain and permission for use is not required. ${ }^{24}$

In addition to the RIPLS, the researchers developed eight statements that asked the participant to use a 5-point Likert scale to rate their familiarity with and understanding of the following statements: characteristics of good teachers and good teaching, essentials of providing effective feedback to learners, elements of effective learner evaluations, ability to utilize an education framework to plan effective teaching encounters, application of using teaching/questioning styles to perform a needs assessment, knowledge of interprofessional practice, knowledge of interprofessional education, and awareness of the Core Competencies for Interprofessional Collaborative Practice document. Questions were also added to collect information about whether participants were currently involved in interprofessional education, and if so, which disciplines were involved. The attendees were asked to complete the survey at the beginning of the course and upon completion of the course. In order to obtain demographic information from each participant, attendees were asked their age, years of practice, discipline, and gender. The instrument, as was used, is found in Appendix 2.

\section{Data Reduction and Analysis}

The responses from paper surveys were entered into a spreadsheet for analysis. IBM SPSS Statistics version 22.0 was used for data analysis. A Kolmogorov-Smirnov test was used to test for normality. Since distribution was not normal and data for the independent variable were nominal and ordinal, nonparametric tests were performed. Response frequencies and percentages for demographic characteristics were calculated. Personal characteristics included gender and age range. The professional characteristics of the respondents include the number of years of experience and professional designation. Numeric values were assigned to responses measured using Likert scales and to other categorical responses to allow for statistical analysis. Descriptive statistics, response frequencies, and percentages were calculated for reported pre and post course familiarity with fundamental concepts of interprofessional teaching (characteristics of good teachers, effective evaluation/feedback, use educational framework to plan encounters, application of teaching/questioning styles to perform needs assessment), and knowledge of interprofessional practice and education.

\section{RESULTS}

Of 43 prospective participants, the response rate for the survey pre-course was 100\% ( $n=43$ ) while the post-course response rate was $91 \%$ ( $n=39$ ). All completed surveys were included in data analysis.

\section{Participant Characteristics}

Eighty-one percent $(n=35)$ of respondents were female and $53.5 \%(n=23)$ were over the age of 40 . In this study, $58.1 \%(n=25)$ of respondents reported 11 or more years of experience. Occupational therapists and physical therapists accounted for the largest portion of the sample $(n=33,76.8 \%)$. Additional details regarding participant characteristics are found in Table 1.

(c) The Internet Journal of Allied Health Sciences and Practice, 2017 
Table 1. Personal and Professional Characteristics of Sample

\begin{tabular}{|l|l|l|l|}
\hline Characteristics & Category & $\begin{array}{c}\text { Number } \\
(\mathrm{n}=43)\end{array}$ & $\begin{array}{c}\text { Percentage* } \\
(\%)\end{array}$ \\
\hline Gender & Male & 7 & 16.3 \\
\hline & Female & 35 & 81.4 \\
\hline Age (years) & 20 to 30 & 8 & 18.6 \\
\hline & 31 to 40 & 12 & 27.9 \\
\hline & 41 to 50 & 12 & 27.9 \\
\hline & 51 to 60 & 9 & 20.9 \\
\hline Experience (years) & 61 or over & 2 & 4.7 \\
\hline & 0 to 5 & 12 & 27.9 \\
\hline & 6 to 10 & 6 & 14.0 \\
\hline & 11 to 15 & 3 & 7.0 \\
\hline Discipline & 16 to 20 & 9 & 20.9 \\
\hline & Over 20 & 13 & 30.2 \\
\hline & Physician Assistant & 5 & 11.6 \\
\hline & Physical Therapist & 18 & 41.9 \\
\hline & Occupational Therapist & 15 & 34.9 \\
\hline & Physician & 1 & 2.3 \\
\hline & Podiatrist & 1 & 2.3 \\
\hline & Psychiatrist & 1 & 2.3 \\
\hline
\end{tabular}

Note: Percentages may not equal $100 \%$ due to missing responses.

Respondents in the current study most often reported positive attitudes about interprofessional learning as displayed in Table 2. The majority of respondents selected either "agree" or "strongly agree" when reporting level of agreement with statements 1 9 which address teamwork and collaboration (92.6\% to $95.4 \%$, respectively) and statements $13-16$ on positive professional identity ( $88.4 \%$ to $97.7 \%$, respectively). "Disagree" or "strongly disagree" was reported by a majority of the respondents when addressing items $10-12$, which were statements on negative professional identity ( $88.4 \%$ to $90.7 \%$, respectively). In spite of overwhelmingly positive responses for item 17 , shared learning, nearly one-third of respondents $(30.2 \%)$ reported uncertainty in professional role in shared learning. 
Table 2. Readiness for Interprofessional Learning Scale Questionnaire Results

\begin{tabular}{|c|c|c|c|c|c|c|c|c|c|c|}
\hline \multirow[t]{3}{*}{ Statement } & \multicolumn{10}{|c|}{ Level of Reported Agreement $(n=43)$} \\
\hline & \multicolumn{2}{|c|}{$\begin{array}{l}\text { Strongly } \\
\text { Disagree }\end{array}$} & \multicolumn{2}{|c|}{ Disagree } & \multicolumn{2}{|c|}{ Undecided } & \multicolumn{2}{|c|}{ Agree } & \multicolumn{2}{|c|}{$\begin{array}{l}\text { Strongly } \\
\text { Agree }\end{array}$} \\
\hline & $\mathrm{n}$ & $\%$ & $\mathrm{n}$ & $\%$ & $\mathrm{n}$ & $\%$ & $\mathrm{n}$ & $\%$ & $n$ & $\%$ \\
\hline $\begin{array}{l}\text { 1. Learning with other students/professionals will } \\
\text { make me more effective }\end{array}$ & 1 & 2.3 & 0 & 0.0 & 1 & 2.3 & 12 & 27.9 & 29 & 67.4 \\
\hline $\begin{array}{l}\text { 2. Patients will ultimately benefit if } \\
\text { students/professionals worked together }\end{array}$ & 1 & 2.3 & 0 & 0.0 & 1 & 2.3 & 9 & 20.9 & 32 & 74.4 \\
\hline $\begin{array}{l}\text { 3. Shared learning with other } \\
\text { students/professionals will increase my ability to } \\
\text { understand clinical problems }\end{array}$ & 1 & 2.3 & 0 & 0.0 & 1 & 2.3 & 10 & 23.3 & 31 & 72.1 \\
\hline $\begin{array}{l}\text { 4. Communication skills should be learned with } \\
\text { other health care students/professionals }\end{array}$ & 1 & 2.3 & 0 & 0.0 & 2 & 4.7 & 11 & 25.6 & 29 & 67.4 \\
\hline $\begin{array}{l}\text { 5. Team-working skills are vital for all health care } \\
\text { students/professionals to learn }\end{array}$ & 1 & 2.3 & 0 & 0.0 & 2 & 4.7 & 4 & 9.3 & 36 & 83.7 \\
\hline $\begin{array}{l}\text { 6. Shared learning will help me to understand my } \\
\text { own professional limitations }\end{array}$ & 1 & 2.3 & 0 & 0.0 & 2 & 4.7 & 12 & 27.9 & 28 & 65.1 \\
\hline $\begin{array}{l}\text { 7. Learning between health care students before } \\
\text { licensure and professionals after licensure would } \\
\text { improve relationships }\end{array}$ & 1 & 2.3 & 0 & 0.0 & 2 & 4.7 & 14 & 32.6 & 26 & 60.5 \\
\hline $\begin{array}{l}\text { 8. Shared learning will help me think positively } \\
\text { about other health professionals }\end{array}$ & 1 & 2.3 & 0 & 0.0 & 2 & 4.7 & 16 & 37.2 & 24 & 55.8 \\
\hline $\begin{array}{l}\text { 9. For small-group learning to work, } \\
\text { students/professionals need to respect and trust } \\
\text { each other }\end{array}$ & 1 & 2.3 & 0 & 0.0 & 1 & 2.3 & 10 & 23.3 & 31 & 72.1 \\
\hline $\begin{array}{l}\text { 10. I don't want to waste time learning with other } \\
\text { health students/professionals }\end{array}$ & 28 & 65.1 & 11 & 25.6 & 1 & 2.3 & 1 & 2.3 & 0 & 0.0 \\
\hline $\begin{array}{l}\text { 11. It is not necessary for postgraduate health } \\
\text { students/professionals to work together }\end{array}$ & 19 & 44.2 & 20 & 46.5 & 4 & 9.3 & 0 & 0.0 & 0 & 0.0 \\
\hline $\begin{array}{l}\text { 12. Clinical problem solving can only be learned } \\
\text { effectively with students/professionals from my } \\
\text { own discipline/ organization }\end{array}$ & 12 & 27.9 & 26 & 60.5 & 3 & 7.0 & 2 & 4.7 & 0 & 0.0 \\
\hline $\begin{array}{l}\text { 13. Shared learning with other health care } \\
\text { professionals will help me to communicate better } \\
\text { with patients and other professionals }\end{array}$ & 1 & 2.3 & 1 & 2.3 & 2 & 4.7 & 19 & 44.2 & 20 & 46.5 \\
\hline $\begin{array}{l}\text { 14. I would welcome the opportunity to work on } \\
\text { small group projects with other health } \\
\text { students/professionals }\end{array}$ & 0 & 0.0 & 0 & 0.0 & 4 & 9.3 & 16 & 37.2 & 23 & 53.5 \\
\hline $\begin{array}{l}\text { 15. I would welcome the opportunity to share } \\
\text { some generic lectures, tutorials, or workshops } \\
\text { with other health care students/professionals }\end{array}$ & 0 & 0.0 & 0 & 0.0 & 5 & 11.6 & 19 & 44.2 & 19 & 44.2 \\
\hline $\begin{array}{l}\text { 16. Shared learning and practice will help me } \\
\text { clarify the nature of patients' or clients' problems }\end{array}$ & 0 & 0.0 & 0 & 0.0 & 1 & 2.3 & 23 & 53.5 & 19 & 44.2 \\
\hline $\begin{array}{l}\text { 17. Shared learning before and after licensure will } \\
\text { help me become a better team worker }\end{array}$ & 0 & 0.0 & 0 & 0.0 & 1 & 2.3 & 22 & 51.2 & 20 & 46.5 \\
\hline $\begin{array}{l}\text { 18. I am not sure what my professional role will } \\
\text { be/is }\end{array}$ & 11 & 25.6 & 17 & 39.5 & 8 & 18.6 & 5 & 11.6 & 0 & 0.0 \\
\hline $\begin{array}{l}\text { 19. I have to acquire much more knowledge and } \\
\text { skill than other students/professionals in my own } \\
\text { faculty/organization }\end{array}$ & 7 & 16.3 & 14 & 32.6 & 17 & 39.5 & 3 & 7.0 & 2 & 4.7 \\
\hline
\end{tabular}

Note: Percentages may not equal $100 \%$ due to missing responses 
Although several respondents indicated no familiarity with one or more of the fundamental concepts of interprofessional teaching techniques, interprofessional education, and interprofessional practice, most reported some level of familiarity as shown in Table 3. Of these concepts, higher levels of familiarity were reported for the interprofessional teaching techniques. Reported levels of familiarity were lower for interprofessional practice and interprofessional education. The lowest levels of familiarity were reported for the document on core competencies for interprofessional practice.

Table 3. Pre Course Self-Reported Familiarity with Concepts of Interprofessional Teaching/Education/Practice

\begin{tabular}{|c|c|c|c|c|c|c|c|c|c|c|c|}
\hline \multirow[t]{3}{*}{ Component } & \multicolumn{11}{|c|}{ Reported Familiarity $(n=43)$} \\
\hline & \multicolumn{2}{|c|}{$\begin{array}{c}1-\text { No } \\
\text { Familiarity }\end{array}$} & \multicolumn{2}{|c|}{2} & \multicolumn{2}{|c|}{3} & \multicolumn{2}{|c|}{4} & \multicolumn{2}{|c|}{5 - Expert } & \multirow[b]{2}{*}{ Median } \\
\hline & $\mathrm{n}$ & $\%$ & $\mathrm{n}$ & $\%$ & $\mathrm{n}$ & $\%$ & $\mathrm{n}$ & $\%$ & $\mathrm{n}$ & $\%$ & \\
\hline $\begin{array}{l}\text { Characteristics of good teachers and good } \\
\text { teaching }\end{array}$ & 0 & 0.0 & 2 & 4.7 & 22 & 51.2 & 17 & 39.5 & 2 & 4.7 & 3.0 \\
\hline Essentials of effective feedback & 0 & 0.0 & 3 & 7.0 & 21 & 48.8 & 16 & 37.2 & 3 & 7.0 & 3.0 \\
\hline Elements of effective learner evaluations & 0 & 0.0 & 8 & 18.6 & 26 & 60.5 & 8 & 18.6 & 1 & 2.3 & 3.0 \\
\hline $\begin{array}{l}\text { Ability to use educational framework to } \\
\text { plan effective teaching encounters }\end{array}$ & 2 & 4.7 & 12 & 27.9 & 20 & 46.5 & 7 & 16.3 & 2 & 4.7 & 3.0 \\
\hline $\begin{array}{l}\text { Application of teaching/questioning styles } \\
\text { to perform a needs assessment }\end{array}$ & 2 & 4.7 & 9 & 20.9 & 22 & 51.2 & 9 & 20.9 & 1 & 2.3 & 3.0 \\
\hline Knowledge of interprofessional practice & 6 & 14.0 & 18 & 41.9 & 12 & 27.9 & 6 & 14.0 & 1 & 2.3 & 2.0 \\
\hline Knowledge of interprofessional education & 9 & 20.9 & 15 & 34.9 & 1 & 2.3 & 11 & 25.6 & 7 & 16.3 & 2.0 \\
\hline $\begin{array}{l}\text { Awareness of Core Competencies for } \\
\text { Interprofessional Collaborative Practice }\end{array}$ & 18 & 41.9 & 1 & 2.3 & 12 & 27.9 & 9 & 20.9 & 3 & 7.0 & 1.0 \\
\hline
\end{tabular}

Of the 43 respondents who participated in the survey, 19 respondents $(44.2 \%)$ reported currently participating in interprofessional education. The reported demographics of the interprofessional education teams varied. Two respondents reported involvement of all 10 disciplines listed on the survey, while the majority of the teams consisted of less than five disciplines (Table 4). Sixteen of the 19 respondents who reported currently participating in interprofessional education also reported student involvement. Table 4 also shows the number of times each type of student was reported to be included in interprofessional education.

\begin{tabular}{|l|c|c|c|l|c|}
\hline \multicolumn{7}{|c|}{ Table 4. Interprofessional Education Teams } \\
\hline Disciplines Involved & $\begin{array}{c}\text { Number of } \\
\text { Times } \\
\text { Discipline } \\
\text { Reported }\end{array}$ & $\begin{array}{c}\text { Reported } \\
\text { Number of } \\
\text { Members } \\
\text { on Team }\end{array}$ & $\begin{array}{c}\text { Number of } \\
\text { Times } \\
\text { Team Size } \\
\text { Reported }\end{array}$ & Students Participating & $\begin{array}{c}\text { Number } \\
\text { Reported }\end{array}$ \\
\hline Dietician & 3 & 1 & 2 & Dietician & 0 \\
\hline Medical Doctor & 8 & 2 & 5 & Medical Doctor & 8 \\
\hline Nurse & 9 & 3 & 2 & Nurse & 4 \\
\hline Occupational Therapist & 12 & 4 & 3 & Occupational Therapist & 7 \\
\hline Pharmacist & 5 & 5 & 1 & Pharmacist & 2 \\
\hline Physical Therapist & 11 & 6 & 1 & Physical Therapist & 7 \\
\hline Physician Assistant & 10 & 7 & 3 & Physician Assistant & 6 \\
\hline Psychiatrist & 6 & 8 & 0 & Psychiatrist & 1 \\
\hline Social Worker & 6 & 9 & 0 & Social Worker & 1 \\
\hline Speech Therapist & 10 & 10 & 2 & Speech Therapist & 4 \\
\hline
\end{tabular}

Following completion of the Interprofessional Clinical Educator Development Workshop, self-reported familiarity of the fundamental concepts of interprofessional teaching, interprofessional practice, and interprofessional education improved for 
most respondents (Figure 1). The median rating for each item increased by more than one level on the five-point Likert scale used to measure familiarity for each item. The highest increase in familiarity was in the area of knowledge of interprofessional practice and education with a $32 \%$ increase.

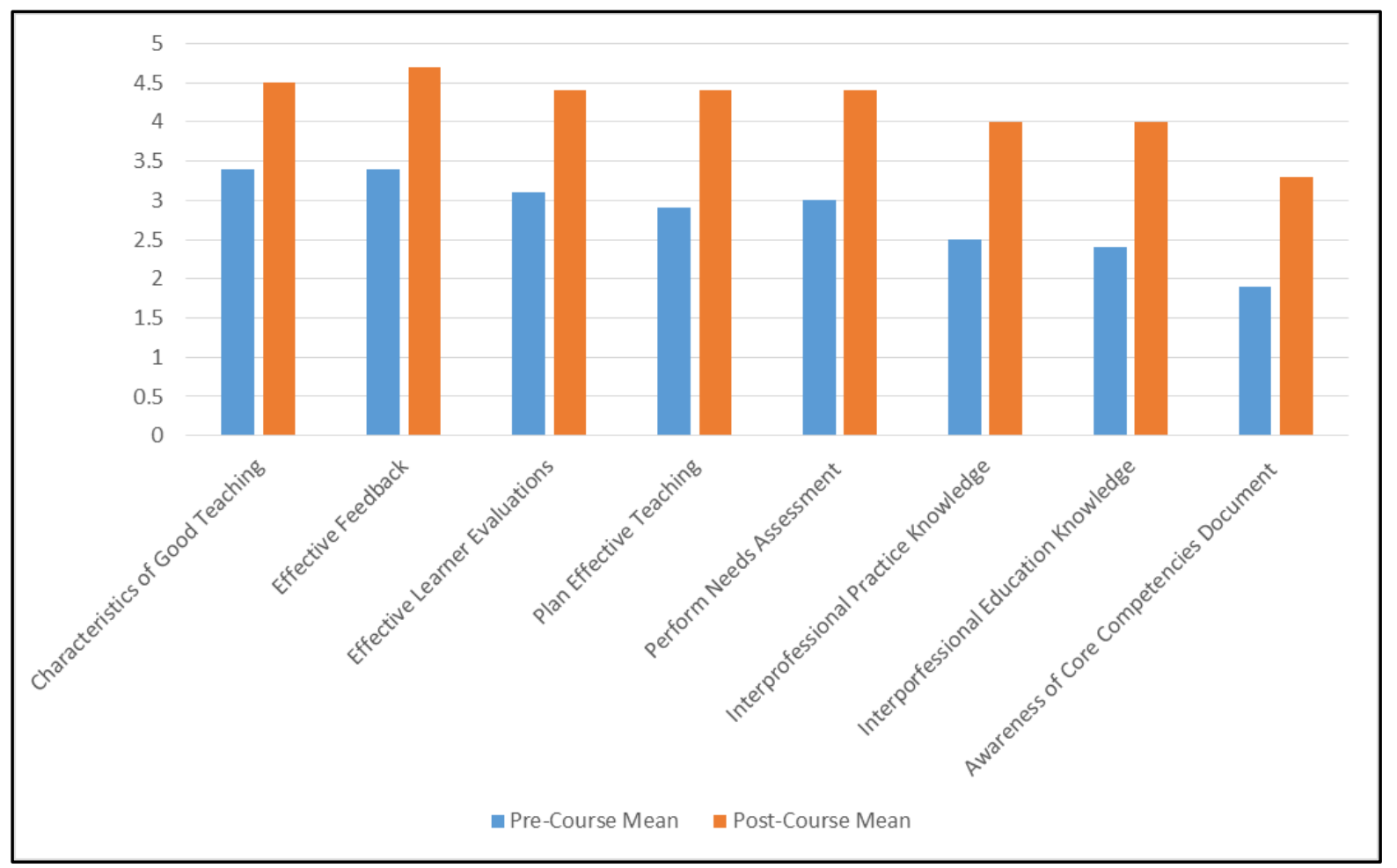

Figure 1. Comparison of Pre and Post Course Median Ratings for Self-Reported Familiarity with Concepts of Interprofessional Teaching/Education/Practice

\section{DISCUSSION}

The purpose of this research study was to examine healthcare professionals' attitude toward interprofessional learning and familiarity with concepts of interprofessional teaching and interprofessional practice, and to examine the influence of an interprofessional clinical educator development workshop on participant familiarity with concepts of interprofessional teaching and learning.

A majority of the participants in this study demonstrated positive attitudes toward the benefits of interprofessional learning. Most agreed or strongly agreed that interprofessional learning would contribute to improved clinical reasoning, the development of positive professional relationships, and a better understanding of the professional roles of others. These are all important aspects of interprofessional practice and have a positive influence on patient care outcomes. ${ }^{1,7,13}$ Less than half of the participants reported currently participating in interprofessional education in the workplace. The majority of participants reported only average, limited, or no familiarity with the Core Competencies for Interprofessional Collaborative Practice, interprofessional education, or interprofessional practice. Self-reported familiarity with the characteristics of good teaching, essentials of effective feedback, effective learner evaluations, and planning effective teaching encounters was higher, with most respondents ranking familiarity at or above the average scale rating. Higher reported levels of familiarity with concepts related to clinical teaching are consistent with the participant's experience as clinical educators involved in the clinical teaching of healthcare professional students. Most have limited or no experience with formally defined interprofessional practice or education which are important to collaborative practice, the provision of patient-centered care, and improved healthcare outcomes. $1,3,7,25$

The Interprofessional Clinical Educator Development Workshop resulted in improvement in the levels of self-reported familiarity of interprofessional teaching, the concepts of interprofessional practice, and interprofessional education. In a post course survey, 
participants were asked, because of their participation in the workshop, what practice and performance changes he/she intended to make that will result in more positive patient outcomes. Responses related to individual performance as a clinician or as a clinical educator, but did not address the integration of any interprofessional teaching, learning, or practice. While the one-day course resulted in participants reporting increased familiarity with the concepts surrounding interprofessional learning and practice, participants did not leave with the intention of adding or enhancing use of these concepts into clinical practice or teaching. The results of the current study do not provide insight into the reason participants did not intend to integrate interprofessional teaching, learning, or practice. One can speculate that higher levels of familiarity and more experience are needed before clinicians would have a comfort level implementing such a change. However, it is also possible that other barriers such as organizational culture, violations of explicit or implicit professional boundaries, or a lack of resources could impede implementation. ${ }^{14,26}$ This would be supported by the response of one participant to a question about suggested topics for future workshops on student clinical instruction, to which the participant responded overcoming obstacles of mentoring a student in another field. Course evaluation results showed that conference attendees valued the workshop and its relevance to clinical instruction, which shows the importance of providing continuing education opportunities for preceptors in spite of organizational challenges encountered in working to coordinate the efforts and roles of different healthcare programs and universities. ${ }^{1}$

\section{Limitations}

One limitation of this study was that it relied upon self-reported data. Although this type of data can provide valuable insight into the respondents' perceptions of interprofessional collaboration and/or education, it may not provide an accurate description of the true interactions among professionals. This sample contained a disproportionately large number of female respondents, most respondents were over the age of 40 with 11 or more years of experience, and physician assistant, physician, and podiatry professions were under-represented. These limitations, combined with a lack of inclusion of other healthcare professions and the small sample size limits the generalizability of these results. Finally, the preponderance of participants who were older and possess more experience may have resulted in sampling bias. This bias could have resulted in either an over-representation or under-representation of attitudes, familiarity with concepts, or pre and post course comparisons because their attitudes or familiarity levels may be much different from those who are younger with less experience.

\section{Practical Implications}

The results of this study reflect the value placed on interprofessional collaborative practice by healthcare professionals, but also identifies a need to improve incorporation of the Core Competencies for Interprofessional Collaborative Practice in both health profession education programs and practice. This is necessary to meet current accreditation expectations for health profession education programs and for improving the healthcare system. ${ }^{5}$ If clinical educators are to be expected to facilitate interprofessional learning experiences in the clinical setting, educational programs must provide clinicians with training in order to achieve this expectation. Implementation of interprofessional education and practice in the clinical setting will not only benefit the academic program and students, but will also result in improvements in clinical practice such as enhanced teamwork, communication, cost reduction, and patient outcomes.1,2,12

\section{CONCLUSION}

While positive attitudes toward interprofessional learning and familiarity with concepts of interprofessional teaching and practice were reported, experience with and participation in interprofessional education in the workplace was quite limited. The results of the current study supports that an educational workshop can positively influence familiarity with interprofessional teaching and practice concepts. However, participation in the course did not contribute to the intention to integrate these concepts into clinical practice or clinical teaching. Alternate strategies need to be considered to facilitate this change. Integrating the Core Competencies for Interprofessional Collaborative Practice into both educational programs and clinical practice will facilitate improved understanding of professional roles and improved collaborative practice. In turn, this will foster the provision of coordinated, high quality, patient centered care that is outcome focused. Further research targeting recent graduates from health profession education programs using a larger sample size and a more proportionate number of respondents from various healthcare professions is encouraged to track trends in interprofessional education and practice. More interprofessional preceptor development programs are recommended to facilitate realistic, interprofessional healthcare training and practices.

\section{References}

1. Barnsteiner JH, Disch JM, Hall L, Mayer D, Moore SM. Promoting interprofessional education. Nurs Outlook. 2007;55(3):144-50. doi:10.1016/j.outlook.2007.03.003. [PMID: 17524802]

2. D'Amour D, Oandasan I. Interprofessionality as the field of interprofessional practice and interprofessional education: an emerging concept. $J$ Interprof Care. 2005;19(Supplement 1):8-20. doi:10.1080/13561820500081604. [PMID: 16096142]

() The Internet Journal of Allied Health Sciences and Practice, 2017 
3. Gilbert JH V, Yan J, Hoffman SJ. A WHO report: framework for action on interprofessional education and collaborative practice. J Allied Health. 2010;39(Special Issue):196-7. [PMID: 21174039]

4. Greidanus E, King S, LoVerso T, Ansell LD. Interprofessional learning objectives for health team simulations. J Nurs Educ. 2013;52(6):311-6. doi:10.3928/01484834-20130509-02. [PMID: 23656376]

5. Schmitt M, Blue A, Aschenbrener CA, Viggiano TR. Core Competencies for Interprofessional Collaborative Practice. Acad Med. 2011;86(11):1351. doi:10.1097/ACM.0b013e3182308e39.

6. Russell L, Nyhof-Young J, Abosh B, Robinson S. An exploratory analysis of an interprofessional learning environment in two hospital clinical teaching units. J Interprof Care. 2006;20(1):29-39. doi:10.1080/13561820500476473. [PMID: 16581637]

7. World Health Organization. Framework for action on interprofessional education \& collaborative practice. 2010:1-64. http://www.who.int/hrh/resources/framework_action/en/. Accessed June 21, 2017.

8. Commission on Accreditation in Physical Therapy Education. PT standards and required elements. 2016. http://www.capteonline.org/AccreditationHandbook/. Accessed June 21, 2017.

9. Accreditation Council for Occupational Therapy Education. 2011 Accreditation Council for Occupational Therapy Education Standards and Interpretive Guide. 2011:1-45.

http://www.aota.org/ /media/Corporate/Files/EducationCareers/Accredit/Standards/2011-Standards-and-InterpretiveGuide.pdf?la=en. Accessed June 21, 2017.

10. Nørgaard B, Draborg E, Vestergaard E, Odgaard E, Jensen DC, Sørensen J. Interprofessional clinical training improves self-efficacy of health care students. Med Teach. 2013;35(6):e1235-42. doi:10.3109/0142159X.2012.746452. [PMID: 23360486]

11. Reeves S, Perrier L, Goldman J, Freeth D, Zwarenstein M. Interprofessional education: effects on professional practice and healthcare outcomes (update). Cochrane Database Syst Rev. 2013;(3):4-47.

doi:10.1002/14651858.CD002213.pub3. [PMID: 23543515]

12. Robertson J, Bandali K. Bridging the gap: enhancing interprofessional education using simulation. $J$ Interprof Care. 2008;22(5):499-508. doi:10.1080/13561820802303656. [PMID: 24567962]

13. Gittell JH, Godfrey M, Thistlethwaite J. Interprofessional collaborative practice and relational coordination: improving healthcare through relationships. J Interprof Care. 2013;27(3):210-3. doi:10.3109/13561820.2012.730564. [PMID: 23082769]

14. Fox A, Reeves S. Interprofessional collaborative patient-centred care: a critical exploration of two related discourses exploration of two related discourses. J Interprof Care. 2015;29(2):113-8. doi:10.3109/13561820.2014.954284. [PMID: 25180630]

15. Association of Schools and Programs of Public Health. Interprofessional collaborative practice model. 2016. http://www.aspph.org/educate/models/interprofessional-collaborative-practicel. Accessed June 21, 2017.

16. Schmitz CC, Cullen MJ. Interprofessional education and collaborative practice: what should I consider when selecting a measurement tool? 2015:1-41. https://nexusipe-resource-exchange.s3.amazonaws.com/EvaluationToolsPaper6-2415.pdf. Accessed June 21, 2017.

17. Marlow SL, Lacerenze C, Iwig C, Salas E. Assessing health care team performance: a review of tools and the evidence supporting their use. 2013:1-48. https://nexusipe-resource-

exchange.s3.amazonaws.com/Assessing\%20Health\%20Care\%20Team\%20Performance\%20for\%20WEBSITE.pdf. Accessed June 21, 2017.

18. National Center for Interprofessional Practice and Education. Assessment and Evaluation. 2013. https://nexusipe.org/advancing/assessment-evaluation. Accessed June 21, 2017.

19. McFadyen A, Webster V, Strachan K, Figgins E, Brown H, McKechnie J. The Readiness for Interprofessional Learning Scale: a possible more stable sub-scale model for the original version of RIPLS. J Interprof Care. 2005;19(6):595-603. doi:10.1080/13561820500430157. [PMID: 16373215]

20. Parsell G, Bligh J. The development of a questionnaire to assess the readiness of health care students for interprofessional learning (RIPLS). Med Educ. 1999;33:95-100. [PMID: 10211258]

21. McFadyen A, Webster V, Maclaren W. The test-retest reliability of a revised version of the Readiness for Interprofessional Learning Scale (RIPLS). J Interprof Care. 2006;20(6):633-9. doi:10.1080/13561820600991181. [PMID: 17095441]

22. Reid R, Bruce D, Allstaff K, McLernon D. Validating the Readiness for Interprofessional Learning Scale (RIPLS) in the postgraduate context: are health care professionals ready for IPL? Med Educ. 2006;40(5):415-22. doi:10.1111/j.13652929.2006.02442.x. [PMID: 16635120]

23. Thannhauser J, Russell-Mayhew S, Scott C. Measures of interprofessional education and collaboration. J Interprof Care. 2010;24(4):336-49. doi:10.3109/13561820903442903. [PMID: 20540613]

(C) The Internet Journal of Allied Health Sciences and Practice, 2017 
24. McFadyen A. Measurement instrument terms of use. 2013:1. https://nexusipe-resourceexchange.s3.amazonaws.com/RIPLS Terms of Use.pdf. Accessed June 21, 2017.

25. Interprofessional Education Collaborative Panel. Core competencies for interprofessional collaborative practice: report of an expert panel. 2011:1-12. http://www.aacn.nche.edu/education-resources/ipecreport.pdf. Accessed June 21, 2017.

26. Brown VT. Interprofessional education - benefits and barriers. Educ Theory Pract. 2009. http://edtheory.blogspot.com/2009/12/by-victoria-t.html. Accessed June 21, 2017. 


\begin{tabular}{|c|c|}
\hline \multicolumn{2}{|r|}{$\begin{array}{c}\text { APPENDIX } 1 \\
\text { AGENDA }\end{array}$} \\
\hline Time & Topic \\
\hline 8:00 AM to 8:10 AM & Welcome and Introductions \\
\hline 8:10 AM to 8:30 AM & $\begin{array}{l}\text { Introduction to Interprofessional Collaborative Practice \& } \\
\text { Interprofessional Education }\end{array}$ \\
\hline 8:30 AM to 8:50 AM & What Makes a Good Teacher? \\
\hline 8:50 AM to 9:05 AM & Educational Planning Process: The GNOME \\
\hline 9:05 AM to 9:50 AM & $\begin{array}{l}\text { Needs Assessment and Questioning Styles } \\
\text { - Demonstration Role Play }\end{array}$ \\
\hline 9:50 AM to 10:05 AM & Break, Transition to Small Groups \\
\hline 10:05 AM to 11:20 AM & $\begin{array}{l}\text { Small Group Practice } \\
\text { - Needs Assessment + Question Styles }\end{array}$ \\
\hline 11:20 AM to 11:25 AM & Transition to Plenary \\
\hline 11:25 AM to 11:55 AM & $\begin{array}{l}\text { Introduction to Evaluation } \\
\quad \quad \text { Direct Observation using Plus/Delta; Demonstration Role Play }\end{array}$ \\
\hline 11:55 AM to 12:55 PM & Lunch \\
\hline 12:55 PM to 1:55 PM & $\begin{array}{c}\text { Feedback and Action Plans } \\
\text { - Demonstration Role Play }\end{array}$ \\
\hline 1:55 PM to 2:05 PM & Transition to Small Groups \\
\hline 2:05 PM to 3:35 PM & $\begin{array}{l}\text { Small Group Practice } \\
\bullet \quad \text { Observation and Feedback }\end{array}$ \\
\hline 3:35 PM to 3:45 PM & Transition to Plenary \\
\hline 3:45 PM to 4:00 PM & Wrap-up \\
\hline
\end{tabular}




\section{APPENDIX 2}

Age: $\square 20-30 \square 31-40 \square 41-50 \square 51-60 \square>60$ Years of practice: $\square 0-5 \square 6-10 \square 11-15 \square 16-20 \square>20$

Your discipline:

Gender: $\square \mathrm{M} \square \mathrm{F}$

On a scale of 1 to 5 ( 1 meaning no familiarity or understanding of the statement to 5 meaning an expert with the statement), please circle the extent of your familiarity with/understanding of the following:

\begin{tabular}{|l|c|c|c|c|c|}
\hline \multicolumn{1}{|c|}{ Objective } & \multicolumn{3}{|c|}{ Rating } & \multicolumn{2}{|c|}{} \\
\hline The characteristics of good teachers and good teaching & 1 & 2 & 3 & 4 & 5 \\
\hline The essentials of providing effective feedback to learners & 1 & 2 & 3 & 4 & 5 \\
\hline The elements of effective learner evaluations & 1 & 2 & 3 & 4 & 5 \\
\hline $\begin{array}{l}\text { The ability to utilize an educational framework to plan effective } \\
\text { teaching encounters }\end{array}$ & 1 & 2 & 3 & 4 & 5 \\
\hline $\begin{array}{l}\text { Application of using teaching/questioning styles to perform a } \\
\text { needs assessment }\end{array}$ & 1 & 2 & 3 & 4 & 5 \\
\hline $\begin{array}{l}\text { Knowledge of interprofessional practice (IPP) } \\
\text { Knowledge of interprofessional education (IPE) }\end{array}$ & 1 & 2 & 3 & 4 & 5 \\
\hline $\begin{array}{l}\text { Awareness of Core Competencies for Interprofessional } \\
\text { Collaborative Practice document }\end{array}$ & 1 & 2 & 3 & 4 & 5 \\
\hline
\end{tabular}

Do you currently participate with interprofessional education at your facility?

Yes

No

If you answered yes to the question above, please circle the health care providers that participate on the interprofessional team.

\begin{tabular}{|l|l|l|l|l|l|l|l|l|l|}
\hline Dietician & $\begin{array}{l}\text { Medical } \\
\text { Doctor }\end{array}$ & Nurse & $\begin{array}{l}\text { Occupational } \\
\text { Therapist }\end{array}$ & Pharmacist & $\begin{array}{l}\text { Physical } \\
\text { Therapy }\end{array}$ & $\begin{array}{l}\text { Physician } \\
\text { Assistant }\end{array}$ & Psychiatrist & $\begin{array}{l}\text { Social } \\
\text { Worker }\end{array}$ & $\begin{array}{l}\text { Speech } \\
\text { Therapist }\end{array}$ \\
\hline
\end{tabular}

Other health care providers:

If you answered yes to the question above, please circle the health care students that participate on the interprofessional team.

\begin{tabular}{|l|l|l|l|l|l|l|l|l|l|}
\hline Dietician & $\begin{array}{l}\text { Medical } \\
\text { Doctor }\end{array}$ & Nurse & $\begin{array}{l}\text { Occupational } \\
\text { Therapist }\end{array}$ & Pharmacist & $\begin{array}{l}\text { Physical } \\
\text { Therapy }\end{array}$ & $\begin{array}{l}\text { Physician } \\
\text { Assistant }\end{array}$ & Psychiatrist & $\begin{array}{l}\text { Social } \\
\text { Worker }\end{array}$ & $\begin{array}{l}\text { Speech } \\
\text { Therapist }\end{array}$ \\
\hline
\end{tabular}

Other health care students:

Readiness for Interprofessional Learning Scale (RIPLS) Questionnaire - The purpose of this questionnaire is to examine the attitude of health and social care students and professionals towards interprofessional learning.

Have you completed the RIPLS questionnaire before? $\square$ Yes $\square$ No

If you answered yes to the previous question, please indicate how long ago you last completed the questionnaire: $\square 1-3$ months $\square 3-6$ months $\square 6-12$ months $\square 1-2$ years $\square 2-3$ years $\square 3+$ years

Have you had previous experience with interprofessional teaching? $\square$ Yes $\square$ No 
If you answered yes to the previous question please give a very brief statement of what this IPE teaching was and any impact it may have had.

\begin{tabular}{|c|c|c|c|c|c|c|}
\hline \multicolumn{7}{|c|}{ Please complete the following questionnaire. } \\
\hline & & $\begin{array}{l}\text { Strongly } \\
\text { Agree }\end{array}$ & Agree & Undecided & Disagree & $\begin{array}{l}\text { Strongly } \\
\text { Disagree }\end{array}$ \\
\hline 1. & $\begin{array}{l}\text { Learning with other students / professionals will make } \\
\text { me a more effective member of a health and social } \\
\text { care team }\end{array}$ & & & & & \\
\hline 2. & $\begin{array}{l}\text { Patients would ultimately benefit if health and social } \\
\text { care students / professionals worked together }\end{array}$ & & & & & \\
\hline 3. & $\begin{array}{l}\text { Shared learning with other health and social care } \\
\text { students / professionals will increase my ability to } \\
\text { understand clinical problems }\end{array}$ & & & & & \\
\hline 4. & $\begin{array}{l}\text { Communications skills should be learned with other } \\
\text { health and social care students / professionals }\end{array}$ & & & & & \\
\hline 5. & $\begin{array}{l}\text { Team-working skills are vital for all health and social } \\
\text { care students / professionals to learn }\end{array}$ & & & & & \\
\hline 6. & $\begin{array}{l}\text { Shared learning will help me to understand my own } \\
\text { professional limitations }\end{array}$ & & & & & \\
\hline 7. & $\begin{array}{l}\text { Learning between health and social care students } \\
\text { before licensure and for professionals after licensure } \\
\text { would improve working relationships after licensure / } \\
\text { collaborative practice. }\end{array}$ & & & & & \\
\hline 8. & $\begin{array}{l}\text { Shared learning will help me think positively about } \\
\text { other health and social care professionals }\end{array}$ & & & & & \\
\hline 9. & $\begin{array}{l}\text { For small-group learning to work, students / } \\
\text { professionals need to respect and trust each other }\end{array}$ & & & & & \\
\hline 10. & $\begin{array}{l}\text { I don't want to waste time learning with other health } \\
\text { and social care students / professionals }\end{array}$ & & & & & \\
\hline 11. & $\begin{array}{l}\text { It is not necessary for postgraduate health and social } \\
\text { care students / professionals to learn together }\end{array}$ & & & & & \\
\hline 12. & $\begin{array}{l}\text { Clinical problem solving can only be learned } \\
\text { effectively with students / professionals from my own } \\
\text { discipline / organization }\end{array}$ & & & & & \\
\hline 13. & $\begin{array}{l}\text { Shared learning with other health and social care } \\
\text { professionals will help me to communicate better with } \\
\text { patients and other professionals }\end{array}$ & & & & & \\
\hline 14. & $\begin{array}{l}\text { I would welcome the opportunity to work on small } \\
\text { group projects with other health and social care } \\
\text { students / professionals }\end{array}$ & & & & & \\
\hline 15. & $\begin{array}{l}\text { I would welcome the opportunity to share some } \\
\text { generic lectures, tutorials or workshops with other } \\
\text { health and social care students / professionals }\end{array}$ & & & & & \\
\hline 16. & $\begin{array}{l}\text { Shared learning and practice will help me clarify the } \\
\text { nature of patients' or clients' problems }\end{array}$ & & & & & \\
\hline 17. & $\begin{array}{l}\text { Shared learning before and after licensure will help } \\
\text { me become a better team worker }\end{array}$ & & & & & \\
\hline 18. & I am not sure what my professional role will be/ is & & & & & \\
\hline 19. & $\begin{array}{l}\text { I have to acquire much more knowledge and skill than } \\
\text { other students / professionals in my own faculty / } \\
\text { organization }\end{array}$ & & & & & \\
\hline
\end{tabular}


If you have any further comments regarding interprofessional education please enter them in the box below

Thank you for completing this survey. The data will provide us with an understanding of the influence of the Interprofessional Clinical Education Workshop. The original RIPLS survey has been adapted for use by the PA, PT and OT Programs of Northern Arizona University and Midwestern University. 